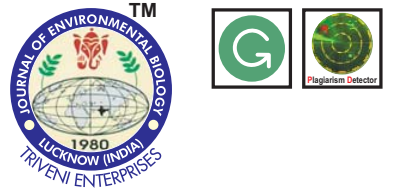

DOI : http://doi.org/10.22438/jeb/38/6/MRN-440

\title{
Impact of rearing temperatures on Tilapia Oreochromis mossambicus growth, muscle morphology and gene expression n expression
}

ISSN: 0254-8704 (Print) ISSN: 2394-0379 (Online) CODEN: JEBIDP

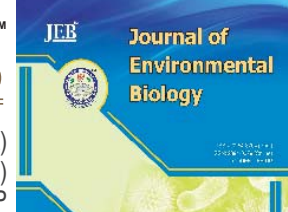

\begin{abstract}
Authors Info
M.P. Brahmane*, B. Sajjanar, N. Kumar, S.S. Pawar, S.K. Bal and K.K. Krishnani

ICAR-National Institute of Abiotic Stress Management, Malegaon, Baramati 413 115, India

*Corresponding Author Email : mbrahmane@yahoo.com
\end{abstract}

\section{Key words}

Gene expression

Hypertrophy

MyoD gene

Myostatin gene

Oreochromis mossambicus

Publication Info

Paper received : 28.08.2016

Revised received : 09.01.2017

Re-revised received: 17.04.2017

Accepted: 10.05.2017

\section{Abstract}

Aim : Oreochromis mossambicus, tilapia is a fast growing fish able to adapt to a range of environmental conditions. The study was conducted with the aim to understand the effect of rearing temperatures on juvenile tilapia growth, muscle cellularity and expression of myoD and myostatin genes.

Methodology : Tilapia larvae were reared at $25^{\circ} \mathrm{C}, 30^{\circ} \mathrm{C}$ and $34^{\circ} \mathrm{C}$ for 60 days. Fish growth was measured in terms of body weight, white muscle fibre frequency through HE staining and qRT-PCR based expression of myoD and myostatin gene.

Results : At 60 day, tilapia juveniles reared at $30^{\circ} \mathrm{C}$ grew significantly higher than $25^{\circ} \mathrm{C}$ and $34^{\circ} \mathrm{C}$, the frequency distribution of white muscle fibres in diameter class $<25 \mu \mathrm{m}$ was similar at $25^{\circ} \mathrm{C}$ and $30^{\circ} \mathrm{C}$, but was significantly higher for fish reared at $34^{\circ} \mathrm{C}$ and of white muscle fibre of diameter $25-50 \mu \mathrm{m}$ was significantly higher at $30^{\circ} \mathrm{C}$ in comparison to $25^{\circ} \mathrm{C}$ and $34^{\circ} \mathrm{C}$. MyoD gene expression was significantly higher at $34^{\circ} \mathrm{C}$ than $25^{\circ} \mathrm{C}$ and $30^{\circ} \mathrm{C}$. Whereas, myostatin expression was similar at all three rearing temperature.

Interpretation : The present investigation suggests that rearing temperature affects fish growth, muscle cellularity and gene expression in juvenile tilapia. Increase in water temperature to $30^{\circ} \mathrm{C}$ is beneficial for achieving maximum body growth and hypertrophic muscle growth in 0 . mossambicus.

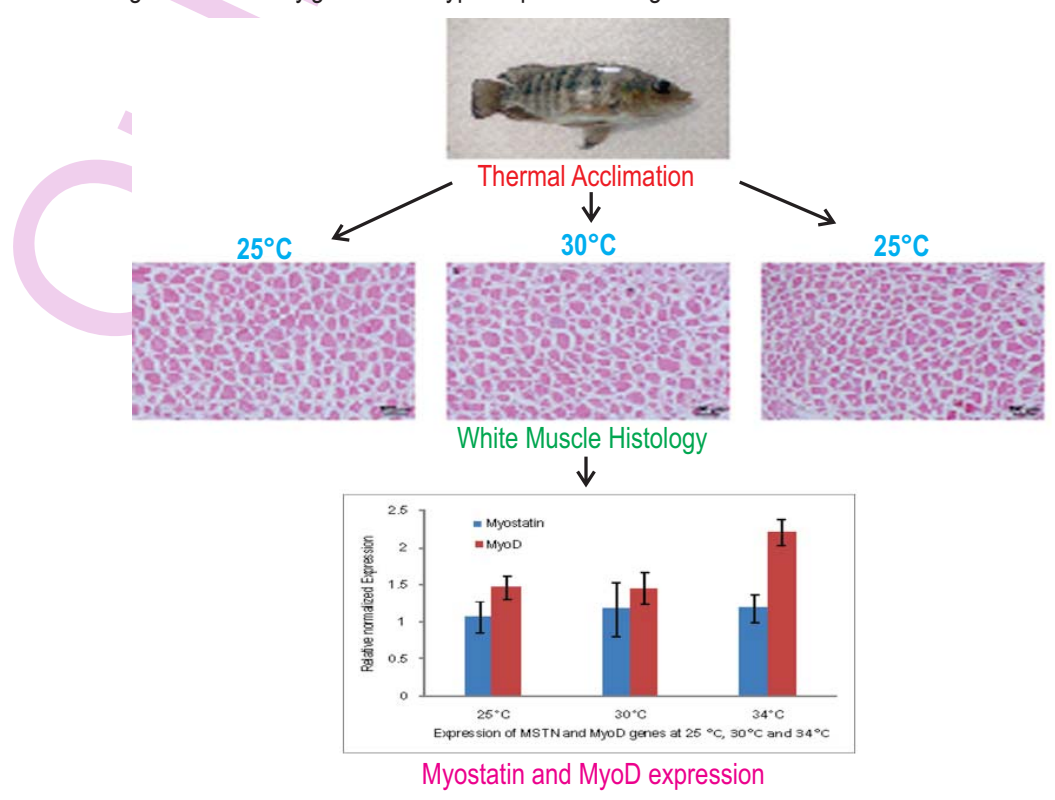




\section{Introduction}

Abiotic factors such as change in habitat temperature, decrease in dissolved oxygen, increase in load of pollutants and their toxicity, change in hydrological regimes, hydrologic variability, eutrophication and so on affect fish and fishery adversely (Ficke et al., 2007). Water temperature and dissolved oxygen affect the growth rate, physiology and reproduction in fish and during the early life stages directly affects the rate of myogenesis, muscle fibre cellularity, expression of genes involved in muscle developmental pathway and growth pattern in adults (de Assis et al., 2004; Johnston, 2006; Alami-Durante et al., 2007; Macqueen et al., 2008; Campos et al., 2013a). Fish skeletal muscles are made up of $70 \%$ white myotomal muscle which exhibit glycolytic metabolism and are composed of fast contracting fibres constituting the bulk of the fish body size (Driedzic and Hochachka, 1976; de Paula et al., 2014; Zhang et al., 1996). In fish, growth is manifested by recruitment and hypertrophy of muscle fibres. The number of muscle fibres recruited to reach a certain girth of fish is influenced by environmental factors including diet, exercise, light and temperatures regimes (Johnston, 1999). The genes and pathways regulating the development of fish muscle are the myogenic regulatory factors. The myogenic regulatory factors (MRFs) are a family of four basic helix-loop-helix transcription factors which are highly conserved between mammals and fish and are responsible in determining muscle lineage (MyoD, Myf5, Mrf4) and for initiation and stabilization of muscle differentiation (Hasty et al., 1993; Kassar-Duchossoy et al., 2004; Rudnicki et al., 1993). Expression of myoD and myf5 occurs before segmentation in adaxial cells in many teleost species (Tan and Jun Du, 2002; Temple et al., 2001; Weinberg et al., 1996). Growth in fish is also regulated by myostatin, also known as growth differentiation factor 8 (Mstn), member of transforming growth factor gene family and is a negative regulator of muscle growth (McPherron et al., 1997). Myostatin is expressed in skeletal muscle in mice (McPherron et al., 1997). It is hypothesized that myostatin may have functions other than muscle growth regulation in tissues other than muscle (Acosta et al., 2005; Ostbye et al., 2001; Lee and McPherron, 2001; Patruno et al., 2008; Rodgers et al., 2001).

Important commercial species of tilapia are Oreochromis mossambicus, 0 . aureus, 0 . niloticus, 0 . hornorum, and 0 . zilli. O. mossambicus is an exotic fish introduced to India in 1952 and has spread throughout the country soon after its introduction due to it being a prolific breeder and its ability to adapt to different environmental conditions which resulted in loss of local fish biodiversity and fishery in several reservoir fisheries in Tamil Nadu, Kerala and Rajasthan. Though O. mossambicus is banned in India since 1959, it is propagating rapidly in wild and constitutes bulk fishery in many reservoirs namely Vaigai, Krishnagiri, Amaravati, Bhavanisagar, Tirumoorthy, Uppar and Pambar reservoirs in Tamil Nadu, Walayar, Malampuzha, Pothundy, Meenkara, Chulliar and Peechi reservoirs of Kerala, Kabini reservoir of Karnataka and Jaisamand Lake of Rajasthan
(Anonymous, 2015). In biofloc system, O. mossambicus average daily growth was $0.405 \mathrm{~g} \mathrm{day}^{-1}$ (Day et al., 2016), growth and specific growth rates were inversely proportional to stocking density (Shubha and Reddy, 2011) and showed significantly higher growth when fed with earthworm meal diet (Bag et al., 2012). Specific growth rate of triploid was 1.097 but hatchability and survivability was low, whereas in diploid 0 . mossambicus specific growth rate was 0.931 with higher egg hatchability and survivability (Nwachi and Esa, 2016). Information on muscle morphology and expression of MyoD and myostatin is meagre.

Demand for fish in India is ever increasing to feed its growing population and tilapia is becoming an important fish species in inland capture fishery. The Ujani reservoir in Maharashtra, India is also heavily populated with tilapia and constitutes a dominant fishery in the reservoir. With increase in demand, tilapia may serve to increase the inland capture fishery production. Thus, the aim of the study was to understand the impact of different rearing temperature on tilapia body growth, muscle growth characteristics and expression of MyoD and myostatin genes.

\section{Materials and Methods}

Fish growth experiment was conducted for a period of 60 days. Tilapia larvae ( $n=108,0.017 \pm 0.001 \mathrm{~g}$ weight,) were distributed into nine aquarium tanks with water temperatures maintained at $25^{\circ} \mathrm{C}, 30^{\circ} \mathrm{C}$ and $34^{\circ} \mathrm{C}$ (triplicates for each group). The fish were fed ad libitum with a commercial feed containing $35 \%$ crude protein throughout the experimental period. Daily, $50 \%$ water was replaced by fresh canal water. The fish were euthanized with MS222 at day 60 and were weighed (gram) and measured (centimeter). Epaxial white muscles below the dorsal fin from fish were collected for muscle histology and gene expression analysis.

White muscle samples were fixed in $10 \%$ buffered formalin and preserved in $70 \%$ ethanol. The samples were dehydrated with a series of ethanol concentration. Transverse sections $(4 \mu \mathrm{m})$ were obtained and stained using hematoxylineosin method. The individual fibre area was measured using a stereo zoom microscope attached with a computerized image analysis system. In this experiment six fish per experimental group were used to measure 200 fibres in random fields of image samples of each fish per experimental group. White muscle fibre diameter (D) was measured from the fibre area $(A)$ by the formula $D=2 A^{0.5} \pi^{-0.5}$ (Valente et al., 1999). For each group, the muscle fibre diameter were grouped into three classes $<25 \mu \mathrm{m}, 25-50 \mu \mathrm{m}$ and $>50 \mu \mathrm{m}$ (de Almeida et al., 2008). Epaxial white muscle was sampled and total RNA was extracted using Tri reagent (Sigma, T9424) according to the manufacturer's protocol. The RNA was quantified using MultiSKan-Go spectrophotometer (Thermo Scientific). RNA quality was assessed using $260 / 280 \mathrm{~nm}$ OD ratio of approximately 2.0. Purified total RNA was reverse transcribed using random hexamer primers and a reverse transcription kit (Thermo fisher). Verso cDNA synthesis kit (Thermo Scientific, 

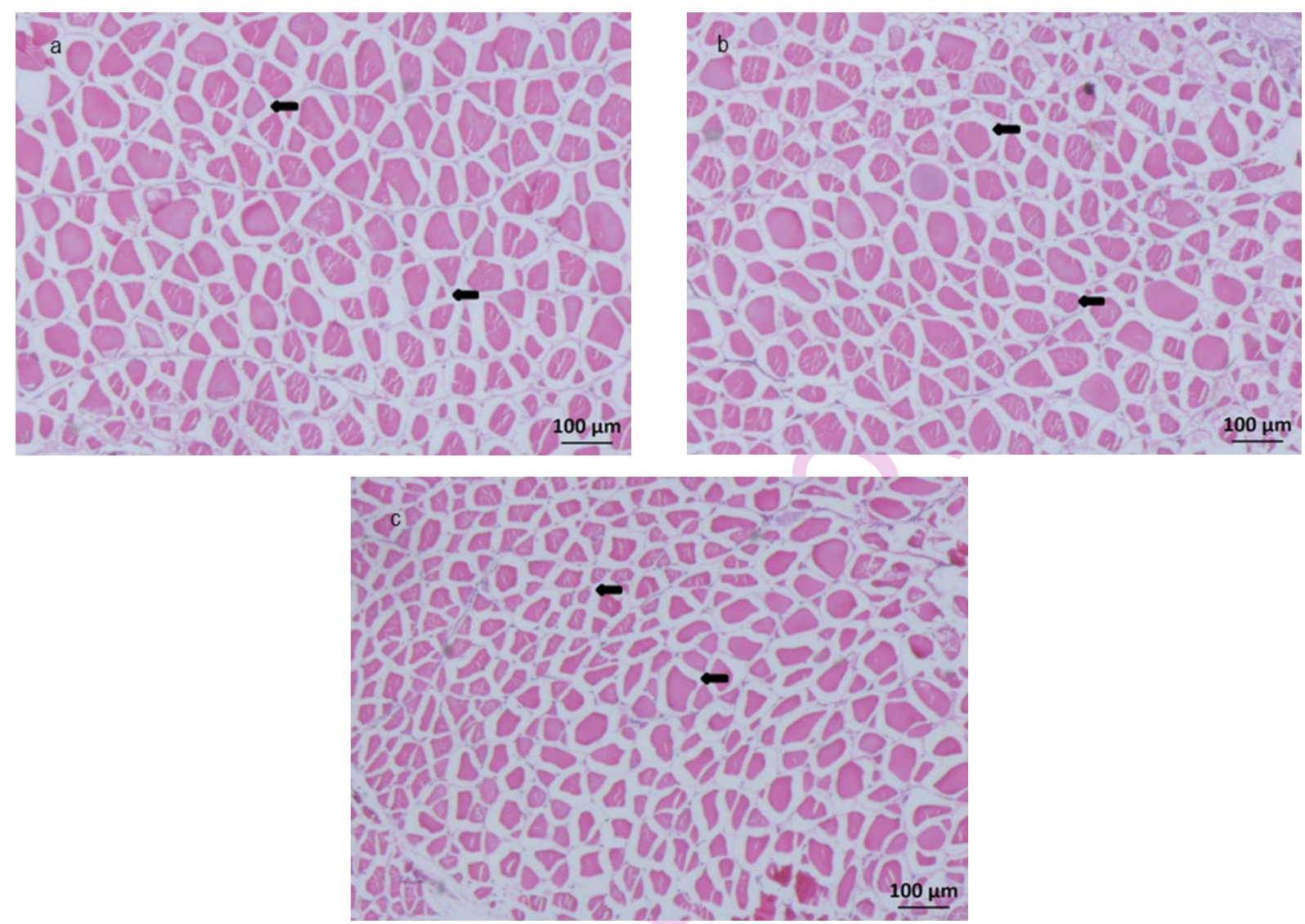

Fig.1: Transverse section of $25^{\circ} \mathrm{C}, 30^{\circ} \mathrm{C}$ and $34^{\circ} \mathrm{C}$ reared tilapia, Oreochromis mossambicus mosaic pattern of small and large (arrow) white muscle

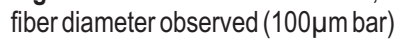

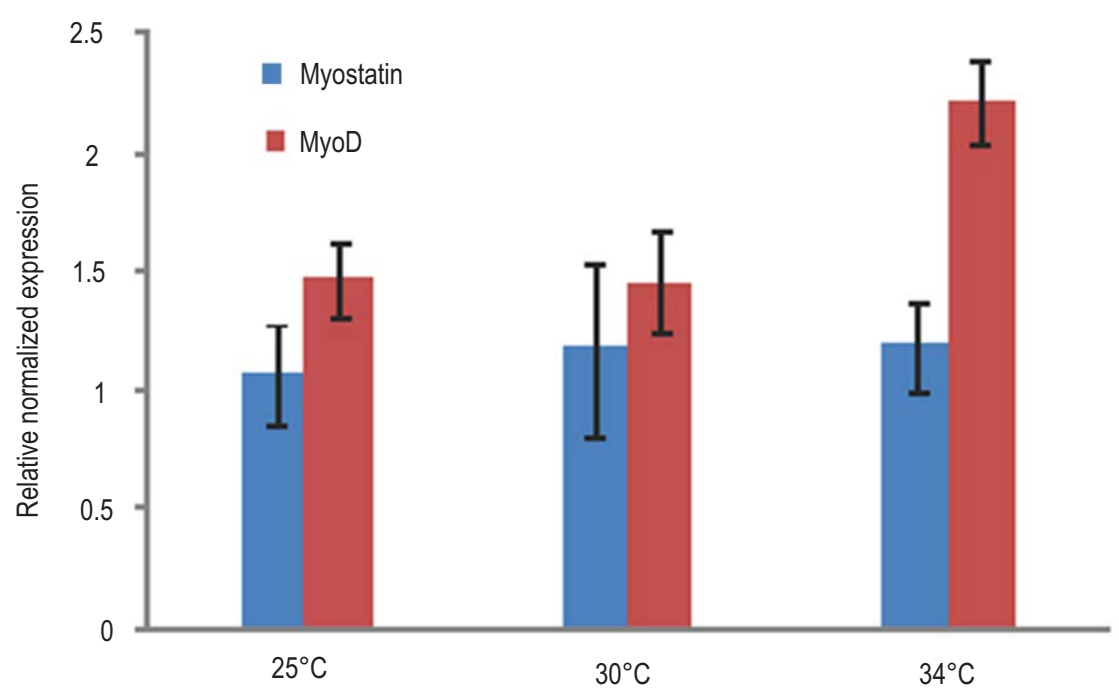

Expression of MSTN and MyoD genes at $25^{\circ} \mathrm{C}, 30^{\circ} \mathrm{C}$ and $34^{\circ} \mathrm{C}$

Fig. 2 : qRT-PCR quantification of myoD and myostatin mRNA expression in white muscle of tilapia Oreochromis mossambicus reared at $25^{\circ} \mathrm{C}$, $30^{\circ} \mathrm{C}$ and $34^{\circ} \mathrm{C}$ 
Table 1 : Oligonucleotide primers used for qRT-PCR amplification of the genes MyoD, myostatin and reference gene $\beta$-actin

\begin{tabular}{llll}
\hline Gene & Sequence $\left(5^{\prime}-3^{\prime}\right)$ & Annealing temperature, ${ }^{\circ} \mathbf{C}$ & Size of amplified fragment (bp) \\
\hline MyoD & Forward: TCA GAC AAC CAG AAG AGG AAG CT & 58 & 60 \\
\multirow{3}{*}{ Myostatin } & \begin{tabular}{l} 
Reverse: CCG TTT GGA GTC TCG GAG AA \\
\multirow{3}{*}{$\begin{array}{l}\text { Forward: TGT GGA CTT CGA GGA CTT TGG } \\
\text { Reverse: TGG CCT TGT AGC GTT TTG GT }\end{array}$}
\end{tabular} & 58 & 59 \\
& $\begin{array}{l}\text { Forward: CCA CAC AGT GCC CAT CTA CGA } \\
\text { Reverse: CCA CGC TCT GTC AGG ATC TTCA }\end{array}$ & 58 & 120 \\
\hline
\end{tabular}

\#AB-1453) was used to prepare cDNA, in which RT enhancer was included to remove the contaminating DNA, eliminating the need for DNAse I treatment. It degraded double stranded DNA during transcription of RNA and was inactivated after 2 min at $95^{\circ} \mathrm{C}$. MyoD and myostatin gene expression was detected by quantitative real time PCR using BioRad CFX 96 real time system C1000 Touch thermal cycler. A sample without cDNA template (NTC) was used to verify that the master mix was free from contaminants. Two microliters of cDNA $(20 \mathrm{~nm} \mu \mathrm{l}-1)$ were amplified with DyNAmo ColorFlash SYBR Green qPCR kit (Thermo Scientific, \#F-416) and $400 \mathrm{~nm}$ of gene specific primer (Table 1) to yield a final volume of $20 \mu \mathrm{l}$. The real time conditions were as follows: initial denaturation at $95^{\circ} \mathrm{C}$ for 3 min followed by 39 cycles of denaturation at $95^{\circ} \mathrm{C}$ for $10 \mathrm{sec}$, and annealing/ extension at $58^{\circ} \mathrm{C}$ for $30 \mathrm{sec}$. The $\beta$-actin gene was used as a reference to normalize the quantification of mRNA target. Primer pairs for MyoD, myostatin and $\beta$-actin were synthesized based on (Nebo et al., 2013; Qiang et al., 2012).

Statistical analysis : The standard length and body weight of fish were analyzed using ANOVA complemented with Multiple Comparison Test (Tukey). The muscle fibre diameters were expressed as frequency percentage. The relative gene expression data were analyzed by Kruskal-Wallis test.

\section{Results and Discussion}

O. mossambicus reared for a period of 60 days exhibited increase in body weight and standard length. At 60 day, tilapia juveniles reared at $30^{\circ} \mathrm{C}$ grew significantly higher $(1.27 \mathrm{~g}$, $139.62 \%)$ than at $25^{\circ} \mathrm{C}(1.42 \mathrm{~g}, 153.57 \%)$ and $34^{\circ} \mathrm{C}(0.82 \mathrm{~g}$, $95.23 \%)$. The hematoxylin-eosin staining showed that the white muscle contributed maximum to the fish muscle mass. The white muscle consisted of round and polygonal fibres separated by endomysium, a fine septum of connective tissue. Muscle fibres were distributed into a mosaic pattern of fibres with different diameters (Fig. 1). At 60 day, the frequency distribution of white muscle fibres in the diameter class $<25 \mu \mathrm{m}$ was similar at $25^{\circ} \mathrm{C}$ and $30^{\circ} \mathrm{C}$, but was significantly higher for fish reared at $34^{\circ} \mathrm{C}$. The frequency distribution of white muscle fibre of diameter $25-50 \mu \mathrm{m}$ was significantly higher at $30^{\circ} \mathrm{C}$ in comparison to $25^{\circ} \mathrm{C}$ and $34^{\circ} \mathrm{C}$, and the larger fibres $>50 \mu \mathrm{m}$ were significantly lower at $30^{\circ} \mathrm{C}$, and were similar at $25^{\circ} \mathrm{C}$ and $30^{\circ} \mathrm{C}$ reared fish (Table 2). Gene expression of muscle genes MyoD and myostatin quantified using RT-qPCR showed changes in fish reared at three different temperatures. At 60 days, the MyoD mRNA level was significantly higher in $34^{\circ} \mathrm{C}$ than $25^{\circ} \mathrm{C}$ and $30^{\circ} \mathrm{C}$ and expression pattern was similar at $25^{\circ} \mathrm{C}$ and $30^{\circ} \mathrm{C}$. The myostatin gene expression did not vary at all the three rearing temperatures (Fig. 2).

The study showed that rearing temperatures affect the fish growth, muscle growth characteristics and expression of muscle myogenic regulatory factor MyoD and myostatin gene in juvenile tilapia, Oreochromis mossambicus. Temperature is one of the most important extrinsic factor modulating growth affecting developmental processes throughout the life of fish (Johnston et al., 2011), affects somatic growth trajectory and the number and size distribution of muscle fibres in juvenile and adult fish (de Paula et al., 2014; Johnston et al., 2009; Macqueen et al., 2008; Stickland et al., 1988). It was observed that higher temperature enhance fish metabolism and feed consumption which results in higher growth (Kieffer et al., 2014). Similarly in the present study, fish exhibited greater growth at rearing temperature of $30^{\circ} \mathrm{C}$ than at $25^{\circ} \mathrm{C}$ and $34^{\circ} \mathrm{C}$. It suggests that temperature of $30^{\circ} \mathrm{C}$ enhances metabolism in tilapia resulting in highest growth of fish. Rearing temperature of $34^{\circ} \mathrm{C}$ induced thermal stress resulting in lower growth of tilapia.

De Paula et al. (2014) subjected pacu fish (Piaractus mesopotamicus) to $24^{\circ} \mathrm{C}, 28^{\circ} \mathrm{C}$ and $32^{\circ} \mathrm{C}$ for a period of 60 days and observed that the body weight was higher at $32^{\circ} \mathrm{C}$ but lower at $24^{\circ} \mathrm{C}$. The frequency distribution of white muscle fibres in the diameter class $<25 \mu \mathrm{m}$ was significantly higher at $24^{\circ} \mathrm{C}$ than $28^{\circ} \mathrm{C}$ and $32^{\circ} \mathrm{C}$, and was similar between $28^{\circ} \mathrm{C}$ and $32^{\circ} \mathrm{C}$. The frequency distribution of $25-50 \mu \mathrm{m}$ diameter fibres were similar at all three temperatures and in class $>50 \mu \mathrm{m}, 32^{\circ} \mathrm{C}$ showed higher percentage than $24^{\circ} \mathrm{C}$. de Assis et al. (2004), observed that pacu eggs incubated at $25^{\circ} \mathrm{C}, 27^{\circ} \mathrm{C}$ and $29^{\circ} \mathrm{C}$ until hatching and reared at room temperature exhibited increase in fibre diameter with increase in temperature. New fibre recruitment was more at $29^{\circ} \mathrm{C}$ than at $25^{\circ} \mathrm{C}$ and $27^{\circ} \mathrm{C}$. Muscle fibre hypertrophy was from hatching to 60 day and the interaction of muscle hypertrophic and hyperplastic growth processes at $29^{\circ} \mathrm{C}$ produced largest fish in the experimental period. Similarly, in this experiment, at 60 days of rearing of 0 . mossambicus, frequency of muscle fibres of class $<25 \mu \mathrm{m}$ showed highest frequency at $34^{\circ} \mathrm{C}$ suggesting that thermal stress at $34^{\circ} \mathrm{C}$ induced muscle fibre recruitment. Frequency distribution of $25-50 \mu \mathrm{m}$ muscle fibre class was highest at $30^{\circ} \mathrm{C}$ suggesting that this temperature condition induces muscle hypertrophy in which fibres expand and absorb satellite cell nuclei to maintain a relatively constant ratio between 
Table 2 : The percentage frequency distribution of white muscle fiber diameter in classes: $<25 \mu \mathrm{m}, 20-50 \mu \mathrm{m}$ and $>50 \mu \mathrm{m}$ of juvenile tilapia reared at $25^{\circ} \mathrm{C}, 30^{\circ} \mathrm{C}$ and $34^{\circ} \mathrm{C}$ for 60 days

\begin{tabular}{llll}
\hline $\begin{array}{l}\text { White muscle } \\
\text { diameter class }(\boldsymbol{\mu m})\end{array}$ & \multicolumn{3}{l}{ Rearing temperatures $\left({ }^{\circ} \mathrm{C}\right)$} \\
\hline & $25^{\circ} \mathrm{C}$ & $30^{\circ} \mathrm{C}$ & $34^{\circ} \mathrm{C}$ \\
$<25$ & $15.29^{\mathrm{a}}$ & $13.76^{\mathrm{a}}$ & $32.52^{\mathrm{b}}$ \\
$25-50$ & $62.60^{\mathrm{a}}$ & $81.60^{\mathrm{b}}$ & $50.93^{\mathrm{c}}$ \\
$>50$ & $22.11^{\mathrm{a}}$ & $4.64^{\mathrm{b}}$ & $16.55^{\mathrm{c}}$ \\
\hline
\end{tabular}

Values with same letters are not statistically significant $(P<0.05)$

the nucleus and cytoplasm of fiber (Koumans and Akster, 1995). In this study, new fibre recruitment was observed in 0 . mossambicus to maintain the somatic growth, even at stressful rearing temperature of $34^{\circ} \mathrm{C}$. Fertilized eggs of Senegalese sole and Solea senegalensis, incubated at $15^{\circ} \mathrm{C}, 18^{\circ} \mathrm{C}$ and $21^{\circ} \mathrm{C}$ till hatching, and subsequently raised the fish at $21^{\circ} \mathrm{C}$ until 30 days post hatch. It was observed that muscle fibers were more at $18^{\circ} \mathrm{C}$ and $21^{\circ} \mathrm{C}$ in comparison to $15^{\circ} \mathrm{C}$ and hypertrophic growth was higher at $18^{\circ} \mathrm{C}$ (Campos et al., 2013b). Similar trend was observed at $30^{\circ} \mathrm{C}$ where muscle hypertrophy was highest.

Skeletal muscle formation in fish involves specific control of several myogenic regulatory factors (MRFs) (Fuentes et al., 2013). These MRFs control cellular specification, activation and differentiation of myogenic cells. The committed and activated cells express myogenic factor 5 (myf5) and myoblast determination factor (myoD) (Watabe, 2001, 1999). In the present study, it was observed that at 60 days of rearing MyoD expression was significantly higher at rearing temperature of $34^{\circ} \mathrm{C}$ than at $25^{\circ} \mathrm{C}$ and $30^{\circ} \mathrm{C}$. It suggests that higher temperature induces expression of MyoD which controls satellite cell proliferation (Kuang and Rudnicki, 2008; Megeney and Rudnicki, 1995; Watabe, 1999). In pacu MyoD expression was higher at $24^{\circ} \mathrm{C}$ and $32^{\circ} \mathrm{C}$ and myostatin gene expression was similar at all rearing temperatures (de Paula et al., 2014). They concluded that rearing at lower temperature alters gene expression and induces delay in muscle growth in juvenile pacu demonstrating thermally induced phenotypic plasticity. At 60 days, the myostatin gene expression did not vary at all rearing temperatures that were evaluated suggesting additional role other than muscle growth regulation in fish (Garikipati etal., 2006, 2007; Ostbye et al., 2001; Radaelli etal., 2003).

This study suggests that temperature affects the growth of 0 . mossambicus. Increase in water temperature to $30^{\circ} \mathrm{C}$ is beneficial for achieving maximum body growth and hypertrophic muscle growth. High temperature $\left(34^{\circ} \mathrm{C}\right)$ inhibits fish growth and induces muscle hyperplasia and higher expression of MyoD gene in O. mossambicus.

\section{Acknowledgment}

The authors thank the Director, ICAR-NIASM, Baramati for providing facilities to conduct the research work.

\section{References}

Acosta, J., Y. Carpio, I. Borroto, O.Gonzalez and M.P Estrada: Myostatin gene silenced by RNAi show a zebrafish giant phenotype. J. Biotechnol., 119, 324-331 (2005).

Alami-Durante, $\mathrm{H}_{\text {., }} \mathrm{N}$. Olive and M. Rouel: Early thermal history significantly affects the seasonal hyperplastic process occurring in the myotomal white muscle of Dicentrarchus labrax juveniles. Cell Tissue Res., 327, 553-570 (2007).

Anonymous.: Guidelines for Responsible Farming of Tilapia in India National Fisheries Development Board, India (2015).

Bag, M.P., S.C. Mahapatra, P.S. Rao and D. Chakrabarty: Evaluation of growth performance of tilapia (Oreochromis mossambicus) using low cost fish feed. Int. J. Biochem, Biotechnol., 1, 150-155 (2012).

Campos, C., J.M.O. Fernandes, L.E.C. Conceicao, S. Engrola, V. Sousa and L.M.P. Valente: Thermal conditions during larval pelagic phase in fluence subsequent somatic growth of Senegalese sole by modulating gene expression and muscle growth dynamics. Aquaculture, 414-415, 46-55 (2013a).

Campos, C., L.M.P. Valente, L.E.C. Conceicao, S. Engrola, V. Sousa, E. Rocha and J.M.O Fernandes: Incubation temperature induces changes in muscle cellularity and gene expression in Senegalese sole (Solea senegalensis). Gene, 516, 209-217 (2013b).

Day, S.B., K. Salie and H.B. Stander : A growth comparison among three commercial tilapia species in a biofloc system. Aquacult Int., 24, 1309-1322 (2016).

de Almeida, F.L.A., R.F. Carvalho, D. Pinhal, C.R. Padovani, C. Martins and M. Dal Pai-Silva : Differential expression of myogenic regulatory factor $\mathrm{MyoD}$ in pacu skeletal muscle (Piaractus mesopotamicus Holmberg 1887: Serrasalminae, Characidae, Teleostei) during juvenile and adult growth phases. Micron, 39, 1306-1311 (2008).

de Assis, J.M.F., R.F. Carvalho, L. Barbosa, C.A. Agostinho and M. Dal Pai-Silva: Effects of incubation temperature on muscle morphology and growth in the pacu (Piaractus mesopotamicus). Aquaculture, 237, 251-267 (2004).

Driedzic, W.R. and P.W. Hochachka: Control of energy metabolism in fish white muscle. Am. J. Physiol., 230, 579-582 (1976).

de Paula, T, G., F.L.A. de Almeida, F.R. Carani, I.J.Vechetti-Junior, C.R. Padovani, R.A.S. Salomao, E.A. Mareco, V.B. dos Santos and M. Dal-Pai-Silva: Rearing temperature induces changes in muscle growth and gene expression in juvenile pacu (Piaractus mesopotamicus). Comp. Biochem. Physiol. B. Biochem. Mol. Biol., 169, 31-7 (2014).

Ficke, A.D., C.A. Myrick and L.J. Hansen: Potential impacts of global climate change on freshwater fisheries, Rev. Fish Biol. Fisher., 17, 581-613 (2007).

Fuentes, E.N., J.A. Valdés, A. Molina and B.T. Bjornsson: Regulation of skeletal muscle growth in fish by the growth hormone--insulin-like growth factor system. Gen. Comp. Endocrinol., 192, 136-48 (2013).

Nwachi, O.F. and Y.B. Esa: Comparative growth and survivalof diploid and triploid Mozambique tilapia (Oreochromis mossambicus) reared in indoor tanks, J. Environ. Biol., 37, 839-843 (2016).

Ostbye, T., T.F. Galloway, C. Nielsen, I. Gabestad, T. Bardal and O. Andersen: The two myostatin genes of Atlantic salmon Salmo salar expressed in a variety of tissues. Eur. J. Biochem., 268, 5249-5257 (2001).

Garikipati, D.K., S.A. Gahr and B.D. Rodgers: Identification, characterization, and quantitative expression analysis of rainbow trout myostatin-1a and myostatin-1b genes. J. Endocrinol., 190, 879-888 (2006). 
Garikipati, D.K., S.A. Gahr, E.H. Roalson and B.D. Rodgers: Characterization of rainbow trout myostatin-2 genes (rtMSTN-2a and $-2 \mathrm{~b}$ ): Genomic organization, differential expression, and pseudogenization. Endocrinology, 148, 2106-2115 (2007).

de Paula, T, G., F.L.A. de Almeida, F.R. Carani, I.J.Vechetti-Junior, C.R. Padovani, R.A.S. Salomao, E.A. Mareco, V.B. dos Santos and M. Dal-Pai-Silva: Rearing temperature induces changes in muscle growth and gene expression in juvenile pacu (Piaractus mesopotamicus). Comp. Biochem. Physiol. B. Biochem. Mol. Biol., 169, 31-7 (2014).

Hasty, P., A. Bradley, J.H. Morris, D.G. Edmondson, J.M. Venuti, E.N. Olson and W.H. Klein : Muscle deficiency and neonatal death in mice with a targeted mutation in the myogenin gene. Nature, 364 , 501-506 (1993).

Johnston, I. A.: Muscle development and growth: Potential implications for flesh quality in fish. Aquaculture, 177, 99-115(1999).

Johnston, I. A.: Environment and plasticity of myogenesis in teleost fish. J. Exp. Biol., 209, 2249-2264 (2006).

Johnston, I. A., H.T. Lee, D.J. Macqueen, K. Paranthaman, C. Kawashima, A. Anwar, J.R. Kinghorn and T. Dalmay: Embryonic temperature affects muscle fibre recruitment in adult zebrafish: genome-wide changes in gene and microRNA expression associated with the transition from hyperplastic to hypertrophic growth phenotypes. J. Exp. Biol., 212, 1781-93 (2009).

Johnston, I. A., N.I. Bower and D.J. Macqueen : Growth and the regulation of myotomal muscle mass in teleost fish. J. Exp. Biol., 214,1617-1628 (2011).

Kassar-Duchossoy, L., B. Gayraud-Morel, D. Gomes, D. Rocancourt, M.Buckingham, V. Shinin and S. Tajbakhsh: Mrf4 determines skeletal muscle identity in Myf5:Myod double-mutant mice. Nature, 431, 466-71 (2004).

Kieffer, J.D., F.M. Penny and V. Papadopoulos: Temperature has a reduced effect on routine metabolic rates of juvenile shortnose sturgeon (Acipenser brevirostrum). Fish Physiol. Biochem. 40 , 551-559 (2014).

Koumans, J.T.M. and H.A. Akster: Myogenic Cells in Development and Growth of Fish. Science, 110A, 3-20 (1995).

Kuang, S. and M.A. Rudnicki: The emerging biology of satellite cells and their therapeutic potential. Trends Mol. Med., 14, 82-91 (2008).

Lee, S.J. and A C. McPherron : Regulation of myostatin activity and muscle growth. Proc. Natl. Acad. Sci. U.S.A., 98, 9306-9311 (2001).

Macqueen, D.J., D.H.F. Robb, T. Olsen, L. Melstveit, C.G.M.Paxton and I. A. Johnston: Temperature until the eyed stage of embryogenesis programmes the growth trajectory and muscle phenotype of adult Atlantic salmon. Biol. Lett., 4, 294-298 (2008).

McPherron, A.C., A.M. Lawler and S.J. Lee: Regulation of skeletal muscle mass in mice by a new TGF-p superfamily member. Nature, 387, 83-90 (1997).

Megeney, L.A. and M.A. Rudnicki : Determination versus differentiation and the MyoD family of transcription factors. Biochem. Cell Biol., 73, 723-32 (1995).

Nebo, C., M.C. Portella, F.R. Carani, F.L.A. de Almeida, C.R. Padovani, R.F.Carvalho and M. Dal-Pai-Silva: Short periods of fasting followed by refeeding change the expression of muscle growth- related genes in juvenile Nile tilapia (Oreochromis niloticus). Comp. Biochem. Physiol. B.,164, 268-274 (2013).

Patruno, M., S. Sivieri, C. Poltronieri, R. Sacchetto, L. Maccatrozzo, T. Martinello, B. Funkenstein and G. Radaelli: Real-time polymerase chain reaction, in situ hybridization and immunohistochemical localization of insulin-like growth factor-I and myostatin during development of Dicentrarchus labrax (Pisces: Osteichthyes). Cell Tissue Res., 331, 643-658 (2008).

Qiang, J., H.Yang, H.Wang, M.D. Kpundeh and P. Xu: Growth and IGF-I response of juvenile Nile tilapia (Oreochromis niloticus) to changes in water temperature and dietary protein level. J. Therm. Biol., 37, 686-695 (2012).

Radaelli, G., A. Rowlerson, F. Mascarello, M. Patruno and B. Funkenstein : Myostatin precursor is present in several tissues in teleost fish: A comparative immunolocalization study. Cell Tissue Res., 311, 239-50 (2003).

Rodgers, B.D., G.M.Weber, C.V. Sullivan and M.A. Levine: Isolation and characterization of myostatin complementary deoxyribonucleic acid clones from two commercially important fish : Oreochromis mossambicus and Morone chrysops. Endocrinology, 142, 14121418 (2001).

Rudnicki, M.A., P.N.J. Schnegelsberg, R.H. Stead, T. Braun, H.H. Arnold and R. Jaenisch : MyoD or Myf-5 is required for the formation of skeletal muscle. Cell, 75, 1351-1359 (1993).

Shubha, M. and S.R. Reddy: Effect of stocking density on growth, maturity, fecundity, reproductive behaviour and fry production in the mouth brooding cichlid Oreochromis mossambicus. Af. J. Biotechnol., 10, 9922-9930 (2011).

Stickland, N.C., R.N. White, P.E. Mescall, A.R. Crook and J.E. Thorpe: The effect of temperature on myogenesis in embryonic development of the Atlantic salmon (Salmo salar L.). Anat. Embryol., 178, 253-257 (1988).

Tan, X. and S. Jun Du: Differential expression of two MyoD genes in fast and slow muscles of gilthead seabream (Sparus aurata). Dev. Genes Evol., 212, 207-217 (2002).

Temple, G.K., N.J. Cole and I. A. Johnston: Embryonic temperature and the relative timing of muscle-specific genes during development in herring (Clupea harengus L.). J. Exp. Biol., 204, 3629-3637 (2001).

Valente, L.M.P., E. Rocha, E.F.S. Gomes, M.W. Silva, M.H. Oliveira, R.A.F. Monteiro and B. Fauconneau: Growth dynamics of white and red muscle fibres in fast- and slow-growing strains of rainbow trout. J. Fish Biol., 55, 675-691 (1999).

Watabe, S.: Myogenic regulatory factors. In: Fish Physiology: Muscle Development and Growth (Ed.: I.A. Johnston). Acadmic Press, pp. 19-41 (2001).

Watabe, S.:Myogenic regulatory factors and muscle differentiation during ontogeny in fish. J. Fish Biol., 55, 1-18 (1999).

Weinberg, E.S., M.L, Allende, C.S, Kelly, A, Abdelhamid, T, Murakami, P, Andermann, O.G. Doerre, D.J. Grunwald and B. Riggleman: Developmental regulation of zebrafish MyoD in wild-type, no tail and spadetail embryos. Development,122, 271-80 (1996).

Zhang, G., D.M. Swank and L.C. Rome: Quantitative distribution of muscle fiber types in the scup Stenotomus chrysops. J. Morphol., 229, 71-81 (1996). 